\title{
Proteome-wide Profiling of Isoniazid Targets in Mycobacterium
}

\section{tuberculosis}

\author{
Argyrides Argyrou $\ddagger, \perp$, Lianji Jin§, Linda Siconilfi-Baez§, Ruth H. Angeletti§, and John S. \\ Blanchard $\ddagger$, \\ $\$$ Department of Biochemistry, Albert Einstein College of Medicine, 1300 Morris Park Avenue, Bronx, NY \\ 10461, USA. \\ $\S$ Laboratory for Macromolecular Analysis \& Proteomics, Albert Einstein College of Medicine, 1300 Morris \\ Park Avenue, Bronx, NY 10461, USA.
}

\section{Abstract}

Isoniazid (INH) is an essential drug used to treat tuberculosis. The mycobactericidal agents are INH adducts (INH-NAD(P)) of the pyridine nucleotide coenzymes, which are generated in vivo after INH activation, and which bind to, and inhibit, essential enzymes. The NADH-dependent enoyl-ACP reductase (InhA) and the NADPH-dependent dihydrofolate reductase (DfrA) have both been shown to be inhibited by INH-NAD $(\mathrm{P})$ adducts with nanomolar affinity. In this paper, we profiled the $M$. tuberculosis proteome using both the INH-NAD and INH-NADP adducts coupled to solid supports and identified, in addition to InhA and DfrA, sixteen other proteins that bind these adducts with high affinity. The majority of these are predicted to be pyridine nucleotide-dependent dehydrogenases/ reductases. They are involved in many cellular processes including $S$-adenosylmethionine-dependent methyl transfer reactions, pyrimidine and valine catabolism, the arginine degradative pathway, proton and potassium transport, stress response, lipid metabolism, and riboflavin biosynthesis. The targeting of multiple enzymes could, thus, account for the pleiotropic effects of, and powerful mycobactericidal properties of, INH.

The powerful and specific antitubercular effects of isoniazid (isonicotinic acid hydrazide, INH) were discovered in 1952, and revolutionized the treatment of tuberculosis (1-3). INH continues to be extensively used in the treatment of the disease to this day; singly in prophylaxis or in a multi-drug combination with rifampicin, pyrazinamide and ethambutol for active infections.

The mechanism by which this simple compound exerts its powerful effect on Mycobacterium tuberculosis (minimum inhibitory concentration, MIC $=0.02-0.05 \mu \mathrm{g} \mathrm{ml}^{-1}$ ) began to be unraveled in the early 1990's shortly after genetic tools for mycobacteria were being developed. Strains of M. tuberculosis and Mycobacterium smegmatis that were resistant to high levels of INH were first shown to have deletions or point mutations in the $k a t G$ gene, which led to the proposal that INH was a pro-drug that was oxidatively activated by the $k a t G$-encoded mycobacterial catalase-peroxidase (4). In a second genetic study, a spontaneous $M$. smegmatis $\mathrm{mc}^{2} 155$ mutant and a Mycobacterium bovis BCG mutant that were co-resistant to

\footnotetext{
*To whom correspondence should be addressed: John S. Blanchard Department of Biochemistry Albert Einstein College of Medicine 1300 Morris Park Avenue Bronx, NY 10461 USA Tel: (718) 430-3096; Fax: (718) 430-8565; E-mail: blanchar@ aecom.yu.edu.

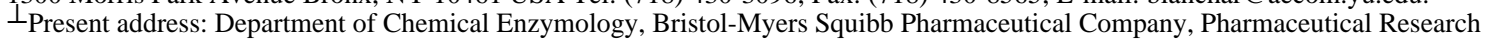
Institute, P.O. Box 5400, Princeton, NJ 08543-5400, USA.

SUPPORTING INFORMATION AVAILABLE

Proteomic analysis of INH-NAD(P)-binding proteins (Supplementary Table 1). This information is available free of charge via the Internet at http://pubs.acs.org.
} 
INH and ethionamide, a structural analog of INH, were both shown to have a point mutation (S94A) in the inhA-encoded enoyl-ACP reductase (5). Furthermore, resistance was observed through overexpression of wild-type InhA or the S94A mutant in M. smegmatis $\mathrm{mc}^{2} 155$, which led to the identification of InhA as a target for INH (5).

A consensus on the mechanism of action of, and resistance to, INH has emerged over the past few years. The oxidation of INH by KatG generates an isonicotinoyl radical that reacts nonenzymatically with cellular pyridine nucleotides to generate an ensemble of isonicotinoylNAD(P) adducts (INH-NAD(P); Figure 1) (6). Of the twelve possible adducts of INH, only two have thus far been shown to inhibit essential enzymes. The acyclic $4 S$ isomer of INH-NAD (compound 1, Figure 1) is known to be a slow-onset, tight-binding inhibitor of $\operatorname{InhA}\left(K_{\mathrm{i}}^{*}=1\right.$ $\mathrm{nM})(7,8)$. Inhibition of InhA prevents the elongation of $\mathrm{C}_{26}$ fatty acids by the fatty acid synthase II complex $(9,10)$, and prevents the formation of the mycolic acids that are an important defense against the host immune surveillance and defense system $(11,12)$. We have recently demonstrated that the acyclic $4 R$ isomer of INH-NADP (compound 4,Figure 1) inhibits the $d f r A$-encoded dihydrofolate reductase (DHFR) with sub-nanomolar affinity, and acts as a bisubstrate analog (13). DHFR maintains the cellular pool of folic acid in the fourelectron reduced form by catalyzing the NADPH-dependent reduction of dihydrofolate (and folate, albeit less efficiently) to tetrahydrofolate (14). By acquiring single-carbon units at the methyl, methylene, and formyl oxidation levels, tetrahydrofolate is an important single-carbon coenzyme donor involved in many important enzymatic reactions, which are necessary for the biosynthesis of nucleic acids, purines, pyrimidines, and several amino acids (14).

Clinical resistance to isoniazid has been increasing rapidly leading to treatment failure and diminished therapeutic outcomes. The appearance of multi-drug resistant tuberculosis (resistance to the two first line drugs, isoniazid and rifampicin) requires the lengthy use of second line drugs that are less effective, more toxic, and more costly than the first line drugs (15). Thus, new anti-tubercular drugs are urgently needed. Effective drug development requires good drug target selection. A powerful way to identify such targets is to identify the targets of existing effective drugs, such as INH against tuberculosis.

Are there other INH targets? The majority of INH-resistant $M$. tuberculosis clinical isolates have mutations in $k a t G$ or inhA, however, 10-25\% of these have unknown genotypes (15) suggesting that there may be additional targets. In addition, the complete genome sequence of M. tuberculosis (16) suggests that, like other organisms, there are a large number of pyridine nucleotide-dependent reductases and dehydrogenases with substrates that could be mimicked by INH-NAD $(\mathrm{P})$ adducts acting as bisubstrate analogs of these enzymes.

Although mycobacterial genetics has continued to provide insight into the mechanisms of resistance to INH (17-19), it has not yet provided any additional INH targets. Genomic (20-24) and proteomic (25) studies have also been employed to identify genes that show altered levels of expression when mycobacteria are treated with INH. However, the RNA and protein levels of KatG, InhA, and DHFR are unaltered after INH treatment and, to date, these studies have failed to provide any new targets for INH. In this paper we employed the old, but extraordinarily powerful, method of affinity chromatography on solid supports to which the INH-NAD and INH-NADP adducts were coupled to effect the selective purification of those enzymes that bind the INH adducts tightly. In addition to InhA and DHFR, we identified sixteen other proteins that bind these adducts tightly. These newly identified proteins are potential candidates for drug development that require further validation including gene knock-out studies to assess essentiality, overexpression of these proteins in M. tuberculosis to determine if they can confer resistance to isoniazid by drug sequestration, recombinant protein expression and purification, assay development to confirm or assign function and determine the extent of 
inhibition of enzyme activity by the INH adducts in vitro, and X-ray crystallography structural studies.

\section{MATERIALS AND METHODS \\ Determination of Protein Concentration}

Protein concentration was determined using the bicinchoninic acid assay kit (PIERCE) and bovine serum albumin as standard (26).

\section{Synthesis and Purification of INH-NAD(P)}

The mixture of INH-NAD $(\mathrm{P})$ adducts were synthesized and purified as described previously $(6,27)$. The $\mathrm{A}_{260 \mathrm{~nm}}$ to $\mathrm{A}_{324 \mathrm{~nm}}$ ratio (an indicator of purity) of the purified products was $3.95-$ 4.00, which is close to the value of 3.94 reported previously for INH-NAD (28). The concentration of INH-NAD(P) was determined from $\varepsilon_{324} \mathrm{~nm}=6900 \mathrm{M}^{-1} \mathrm{~cm}^{-1}$ reported previously for INH-NAD (28).

\section{Preparation of INH-NAD(P)-Sepharose}

Three milliliters of $N$-hydroxysuccinamideactivated Sepharose 4 fast flow resin (Amersham Biosciences) was washed with $10 \mathrm{ml}$ of icecold $1 \mathrm{mM}$ hydrochloric acid. NAD(P) ${ }^{+}$was first covalently attached via the exocyclic adenine amine to the resin by suspending the beads in 10 $\mathrm{ml}$ of $100 \mathrm{mM} \mathrm{NAD}(\mathrm{P})^{+}$dissolved in $100 \mathrm{mM}$ Pipes buffer, $\mathrm{pH}$ 7.5. This reaction was allowed to proceed for $20 \mathrm{~h}$ at room temperature by end-over-end mixing. Unreacted sites were then blocked by washing the resin twice with $10 \mathrm{ml}$ of $100 \mathrm{mM}$ Tris, $\mathrm{pH} 8.0$ and stored at $4{ }^{\circ} \mathrm{C}$ for $24 \mathrm{~h}$. After washing thoroughly with $100 \mathrm{mM}$ sodium phosphate, $\mathrm{pH} 7.5$, INH $(2 \mathrm{mM})$ and $\mathrm{Mn}$ (III) pyrophosphate $(4 \mathrm{mM})$ were added to the $\mathrm{NAD}(\mathrm{P})^{+}-$Sepharose resin with gentle magnetic stirring to generate the INH-NAD(P) inhibitor. $\mathrm{Mn}(\mathrm{III})$ pyrophosphate (6) was added in onetenth portions every $2 \mathrm{~min}$ (the final resin suspension volume was $15 \mathrm{ml}$ ). The INH-NAD(P)sepharose suspension was then poured into a $50 \mathrm{ml}$ disposable column (BIO-RAD) and washed extensively with $50 \mathrm{mM}$ sodium phosphate, $\mathrm{pH} 7.0$, containing $100 \mathrm{mM} \mathrm{NaCl}$, and $1 \mathrm{mM}$ EDTA (buffer A). The final bed volume of the columns was $2 \mathrm{ml}$.

\section{Isolation of INH-NAD(P)-binding Proteins}

M. tuberculosis $\mathrm{H} 37 \mathrm{Rv}$ whole cell lysate $\left(10 \mathrm{ml}\right.$ of $20 \mathrm{mg} \mathrm{ml}^{-1}$ protein, generously provided by the Tuberculosis Vaccine Testing and Research Materials Contract of the Colorado State University) was supplemented with 2 tablets of complete protease inhibitor cocktail (Roche) and $1 \mathrm{mM}$ EDTA and centrifuged at $20,000 \mathrm{~g}$ for $30 \mathrm{~min}$ at $4{ }^{\circ} \mathrm{C}$. The supernatant was then dialyzed for $2 \mathrm{~h}$ against $4 \mathrm{~L}$ of buffer A at $4{ }^{\circ} \mathrm{C}$. Half of the dialysate was applied to the INH$\mathrm{NAD}(\mathrm{P})$-sepharose column while the other half was applied to the $\mathrm{NAD}(\mathrm{P})^{+}$-sepharose control column without flow. The columns were capped, the resin suspended, and binding of proteins to the resin was allowed to proceed for $2 \mathrm{~h}$ at $4{ }^{\circ} \mathrm{C}$ by end-over-end mixing. The resin was then allowed to settle and the chromatography procedure initiated at room temperature. After discarding the unbound proteins, the columns were washed with $50 \mathrm{ml}$ of buffer A followed by $20 \mathrm{ml}$ of $1 \mathrm{mM} \mathrm{NAD}(\mathrm{P})^{+}$in buffer A to remove weakly bound dehydrogenases. Two $\mathrm{ml}$ of $3.5 \mathrm{mM}$ INH-NAD(P) inhibitor was then applied to the columns and the inhibitor allowed to enter the resin. Flow was stopped and equilibration was allowed to proceed for $1 \mathrm{~h}$. The eluted proteins were collected and combined with the eluate after applying $4 \mathrm{ml}$ of buffer A to the columns. These combined fractions were then concentrated to $50 \mu \mathrm{l}(\sim 50 \mu \mathrm{g}$ total protein) using a centrifugal filter device through a $10 \mathrm{kDa}$ cut-off membrane (Millipore) and the proteins were analyzed by SDS-PAGE followed by silver-staining. 


\section{Identification of INH-NAD(P)-binding Proteins}

Protein bands were excised from the gels, reduced, alkylated with iodoacetamide, and digested with proteomics-grade trypsin (Promega). The resulting tryptic peptide mixture was then analyzed by liquid chromatography combined with on-line electrospray mass spectrometry. Peptides were separated on a C18 PepMap 100 column $(75 \mu \mathrm{m} \times 15 \mathrm{~cm}$; Dionex $)$ at a constant flow-rate of $250 \mathrm{nl} \mathrm{min}-1$ as follows: 20 min at $2 \% \mathrm{~B}, 15$ min linear gradient from $2 \%$ to 52 $\% \mathrm{~B}$, and $5 \mathrm{~min}$ at $90 \% \mathrm{~B}$. Solvent A consists of $2 \%(\mathrm{v} / \mathrm{v})$ acetonitrile and $0.08 \%(\mathrm{v} / \mathrm{v})$ formic acid while solvent B consists of $80 \%$ (v/v) acetonitrile and $0.1 \%$ (v/v) formic acid. The eluent was directly introduced into the electrospray port of a Finnigan LTQ Linear Ion Trap mass spectrometer (Thermo Electron). The mass spectrometry data were acquired in data dependent mode. The MS survey scan was recorded between $\mathrm{m} / \mathrm{z}$ 300-2000, which was then followed by MS/MS scans of the three most intense ions. The normalized collision energy was set at $35 \%$, the repeat count of dynamic exclusion was set at 2 and the exclusion duration at $180 \mathrm{~s}$.

\section{Database Search and Data Analysis}

The raw data file was converted into a peaklist using an in-house script (RawFileExtractor), and was then searched against the non-redundant NCBI database for proteins from the $M$. tuberculosis complex using the Mascot search engine. The search criteria were as follows: 2 missed cleavages by trypsin were allowed; carboxamidomethylation of cysteine residues was fixed; modification of methionine residues by oxidation was allowed to vary; the mass tolerance for the peptide was set at $2 \mathrm{Da}$ while the MS/MS tolerance was set at $0.8 \mathrm{Da}$. Positive protein identification requires a minimum of two unique peptides with peptide ion scores $\geq$ MOWSE score.

\section{RESULTS}

\section{Purification of INH-NAD(P)-binding proteins}

To isolate proteins from M. tuberculosis that bind INH-NAD(P) with high affinity, we covalently linked INH-NAD(P) onto column supports and affinity-purified those proteins from M. tuberculosis crude soluble cell extracts that bind these adducts with high affinity (Methods). After extensive washing with buffer and either $\mathrm{NAD}^{+}$or NADP ${ }^{+}$, specific elution of INH-NAD (P)-binding proteins was accomplished using the same INH-NAD(P) adduct pool that was covalently attached to the columns. From $100 \mathrm{mg}$ of $M$. tuberculosis crude soluble protein cell extract, approximately $50 \mu \mathrm{g}$ of total protein was recovered from solid supports containing the covalently coupled INH-NAD(P) adducts, representing an approximately 2000-fold enrichment of proteins that were bound to the coupled adducts. Figure 2 shows silver-stained SDS-PAGE gels of the final INH-NAD(P) protein eluates from the NAD $(\mathrm{P})^{+}$-Sepharose and INH-NAD(P)-Sepharose columns.

\section{Identification of INH-NAD(P)-binding proteins}

Protein bands from the INH-NAD $(\mathrm{P})$ protein eluates of the INH-NAD(P)-Sepharose columns were excised for in-gel trypsin digestion followed by analysis of the peptides by liquid chromatography coupled to mass spectrometry (Methods). Table 1 lists the identity of the proteins, their molecular weight, their annotated function, whether they are predicted to bind pyridine nucleotides, and whether they are essential for mycobacterial growth in liquid culture. Supplementary Table 1 gives additional information including the accession numbers, overall protein score, number of unique peptides detected for each protein, the sequence and score for each unique peptide, and the sequence coverage for each protein in Table 1. We note that bands $1,3,5,8$, and 10 contain more than one protein species with similar molecular weights that were not resolved by SDS-PAGE (see Table 1). 


\section{DISCUSSION}

\section{The Power of INH-NAD(P) Affinity Chromatography}

Large amounts of $M$. tuberculosis cell extract are difficult to obtain because of the organism's highly infective nature, requiring high-level safety containment, and its unusually slow doubling time of 18-24 h. These realities present significant challenges to performing biochemical characterizations in this organism, and in the present study, we were restricted to a total of approximately $400 \mathrm{mg}$ of $M$. tuberculosis crude soluble protein cell extract to perform all the experiments presented in this paper. We developed a one-step INH-NAD(P)-affinity chromatography purification method (see Methods section) that permitted the highly selective purification and identification of proteins that bind INH-NAD(P) with high affinity (see below), which is similar to a general procedure that has recently been introduced (29). The known three-dimensional structures of the $4 S$-isonicotinoyl- NAD adduct bound to InhA and the $4 R$-isonicotinoyl-NADP adduct bound to DHFR revealed that in these two known targets, there are essentially no interactions between the exocyclic adenine amine of the adducts and the enzyme $(8,13)$. We thus elected to covalently couple the adducts via this position using $\mathrm{N}$-hydroxysuccinamide-activated Sepharose (Methods). From $100 \mathrm{mg}$ of M. tuberculosis crude soluble protein cell extract, approximately $50 \mu \mathrm{g}$ of total protein was recovered from solid supports containing the covalently coupled INH-NAD $(\mathrm{P})$ adducts. This amount of protein, specifically eluted by the identical adduct pool that was covalently bound to the columns, was sufficient to obtain the identity of all the protein bands in the two silver-stained gels shown in Figure 2. We note that because of the stereochemically-uncontrolled nature of the nonenzymatic reaction between activated isoniazid and pyridine nucleotides, as well as the subsequent spontaneous, but reversible, cyclization of the acyclic forms (compounds $\mathbf{1}$ and 4; Figure 1) to generate the corresponding cyclic forms (compounds 2, 3, 5, and 6; Figure 1), the proteins we isolated could, in principle, bind any of the six isomers of INH-NAD(P) shown in Figure 1.

\section{INH-NAD(P) Affinity Chromatography is Highly Selective}

To determine the selectivity of our approach, we analyzed the final INH-NAD(P) protein eluates from the INH-NAD(P)-Sepharose as well as from the NAD $(\mathrm{P})^{+}$-Sepharose columns by SDS-PAGE followed by silverstaining (Figure 2). Most of the proteins that bind to the INH$\mathrm{NAD}(\mathrm{P})$ columns are unique when compared to the corresponding proteins that bind to the $\mathrm{NAD}(\mathrm{P})^{+}$-Sepharose control columns (lane 2 versus 1 , and lane 4 versus 3, Figure 2) demonstrating the high selectivity of this method for the proteins of interest. In addition, the profile of proteins bound to the columns containing covalently bound INH-NAD is completely different from that of the INH-NADP column (lane 2 versus 4, Figure 2) as expected, since most dehydrogenases are specific for either the nonphosphorylated (NADH) or phosphorylated (NADPH) forms of the pyridine nucleotides. Finally, band 4, which is the most intense band in lane 2, was unambiguously identified as InhA, a known and validated target of INH. Moreover, even though no silver-stained band is observed within the box marked 11 in lane 4, probably reflecting its low cellular abundance, we excised this gel-slice because it corresponds to the position in the gel where DHFR was expected to migrate, and we detected a single DHFR tryptic peptide with a high score from this region after in-gel digestion. The isolation of InhA and DHFR, the only two M. tuberculosis proteins known to bind INH-NAD(P) adducts with sub- to low-nanomolar affinity $(7,13)$, demonstrates that the method is successful at isolating the known high-affinity INH-NAD(P)-binding proteins. We note that identification of the proteins in the final INH-NAD $(\mathrm{P})$ eluates from the $\mathrm{NAD}(\mathrm{P})^{+}$- Sepharose control columns was not attempted as these proteins appear to have a high affinity for $\mathrm{NAD}(\mathrm{P})^{+}$since the prior 1 mM NAD $(\mathrm{P})^{+}$wash was not sufficient to remove them from the columns. Thus, endogenous $\mathrm{NAD}(\mathrm{P})^{+}$is expected to protect these proteins from $\mathrm{INH}-\mathrm{NAD}(\mathrm{P})$ inhibition in vivo. 
INH has also been proposed to target the kasA-encoded $\beta$-ketoacyl ACP synthase (30). This enzyme is also a component of the fatty acid synthase II complex and it catalyzes the condensation of malonyl-ACP with acyl-ACP during each elongation cycle of fatty acid biosynthesis. The observation of a covalent complex between KasA, AcpM, and INH in isoniazid-treated $M$. tuberculosis led to the proposal that KasA was the primary target for INH (30). We note that since the KasA-catalyzed reaction is not pyridine nucleotide-dependent, it is not surprising that we did not isolate this protein using our method.

\section{High-Affinity INH-NAD(P)-binding Proteins}

Of the eighteen proteins listed in Table 1, only InhA and DHFR have previously been demonstrated to be inhibited by INH-NAD(P). Nine others are predicted to be pyridine nucleotide dependent dehydrogenases/reductases. SahH (Rv3248c), which codes for $S$ adenosylhomocysteine hydrolase, is not a dehydrogenase/reductase but uses a tightly-bound pyridine nucleotide coenzyme, which cycles between the $\mathrm{NAD}^{+}$and NADH oxidation states, to catalyze the cleavage of the homocysteine moiety of $S$-adenosylhomocysteine (31-33). CeoB/TrkA (Rv2691) shares $24 \%$ sequence identity with the Escherichia coli TrkA protein, which codes for the $\mathrm{NAD}^{+}$-binding subunit of the potassium transport system. It is interesting to note that the $M$. tuberculosis $\mathrm{CeoB} /$ TrkA gene had previously been identified in a novel selection for INH resistance in an E. coli oxyR strain, which is more susceptible to INH and hydrogen peroxide than the parent strain (34). The open reading frames, Rv0926c and Rv1059, which share $32 \%$ sequence identity with one another, have unknown function, but examination of the two aligned amino acid sequences shows that they have a GXGXXG amino acid motif (35) near their N-termini, an indicator that they could bind pyridine nucleotides.

As with any method, it is likely that there will be some false positives. Rv2623 and Rv1996, for example, which share $40 \%$ sequence identity with one another, are predicted to be universal stress proteins, which bind and hydrolyze ATP (36). A large body of evidence suggests that Rv2623 is important for the non-replicating persistence state of M. tuberculosis: Rv2623 has been shown to be induced under hypoxic conditions $(37,38)$, in standing cultures (39), upon macrophage phagocytosis (40), and during lung infection (41). M. tuberculosis has been termed "the world's most successful pathogen" in part because of its ability to persist inside the human host for years or decades without causing fulminant disease, resulting in the infection of onethird of the human population (42). It is possible that Rv2623 and Rv1996 were identified using our method because they bind to the ADP portion of the INH-NAD inhibitor. However, their absence in lane 1 (Figure 2), and the probability that they would have been removed in the 1 $\mathrm{mM} \mathrm{NAD}^{+}$wash suggests that this is unlikely. Expression and purification of these proteins is required to verify their annotated function as well as their ability to bind INHNAD. Finally, $\mathrm{Mtn} / \mathrm{Sah}$ (Rv0091), which codes for a bi-functional 5'-methylthioadenosine/ $S$ -

adenosylhomocysteine nucleosidase does not use pyridine nucleotides as substrates. It is possible that it has high affinity for a protein that binds to INH-NAD-Sepharose, for example $S$-adenosylhomocysteine hydrolase (above), resulting in the co-purification of these two proteins as a complex. Again, expression and purification of $\mathrm{Mtn} / \mathrm{Sah}$ is required to determine if it has the ability to independently bind to, and be inhibited by, INH-NAD.

\section{The Pleiotropic Effects of INH}

An important, as yet unanswered, question is which of the twelve INH-NAD(P) adducts is/are the active forms of the drug ? Mutations in the promoter region and within the structural gene of inhA have been identified in INH-resistant M. tuberculosis clinical isolates that confer lowlevel resistance to isoniazid $(15,43,44)$. Since InhA binds the acyclic $4 S$ isomer of the INHNAD adduct (compound 1, Figure 1), one might argue that this or one of its two equilibrating cyclic forms (compounds 2 and 3, Figure 1) is/are the bactericidal species and that the remaining nine adducts, although they do form in vivo, do not inhibit significantly any other 
essential enzyme in vivo. However, these mutations confer only low-level resistance to isoniazid $(15,43,44)$. In addition, the purified recombinant InhA structural mutants still bind tightly and are inhibited potently by compound $1\left(K_{\mathrm{i}}^{*}=2.3-5.3 \mathrm{nM}\right)(7)$ suggesting that the mechanism of action of isoniazid is more complex than simply inhibiting a single enzyme target.

INH has previously been shown to inhibit mycolic acid (45-47) and nucleic acid biosynthesis in vitro (48). INH has also been proposed to affect $\mathrm{NAD}^{+}$and pyridoxal phosphate metabolism by acting as an antimetabolite of these coenzymes $(2,47)$. In addition to InhA and DHFR, we have found sixteen other enzymes that bind tightly to, and could be inhibited by INHNAD(P). These are involved in an extraordinary variety of cellular processes including $S$ adenosylmethionine-dependent methyl transfer ( $\mathrm{SahH}$, see below), pyrimidine and valine catabolism (MmsA), the arginine degradative pathway (RocA), proton and potassium transport (PntAA and CeoB/TrkA, respectively), stress response (Rv2623 and Rv1996), lipid metabolism (FadB2 and FabG5), riboflavin biosynthesis (RibD), and various pyridine nucleotide-dependent redox reactions of unknown biochemical function (AldC, Rv3777, and Rv2971). The high-density mutagenesis study of Sasseti et al. (49), which identified candidate genes required for normal growth but which require individual confirmation, suggests that four of these new targets (SahH, Rv2623, Rv2971 and Rv1187) are essential for optimum growth of M. tuberculosis in vitro (49). We note that some genes, which are not essential for mycobacterial growth in vitro may be essential for growth in vivo. Thus, INH has multiple targets, and it may be that the simultaneous inhibition of these multiple enzymatic targets results in the thoroughly documented bactericidal effects of INH treatment, resulting in cell lysis.

Inhibition of a specific cellular process by INH could also be the result of inhibition of multiple enzymes involved in the same biosynthetic process. Inhibition of mycolic acid biosynthesis, for example, has been credited to inhibition of InhA $(10,15)$ or KasA $(30)$, both of which are components of the type II fatty acid synthase complex (9). Mycolic acids are decorated with various functional groups including cyclopropyl, keto, and methoxy groups, which are essential for $M$. tuberculosis survival within macrophages $(11,12)$. The methoxy groups are introduced by $S$-adenosylmethionine-dependent methyltransferases (12). Since most methyltransferases are product-inhibited by $S$-adenosylhomocysteine, cells have evolved $S$ adenosylhomocysteine hydrolase ( $\mathrm{SahH}, \mathrm{Rv} 3248 \mathrm{c}$ ), to keep the cellular levels of $S$ adenosylhomocysteine low $(32,33)$. We suggest that by inhibiting SahH, the INH-NAD adduct would indirectly interfere with these essential steps in mycolic acid maturation. We have recently proposed that inhibition of nucleic acid biosynthesis by INH results from inhibition of DHFR by INH-NADP (48). By inhibiting SahH, INH would additionally, though indirectly, inhibit the methyltransferases involved in the methylation of uracil and cytosine residues in tRNA by the accumulation of $S$-adenosylhomocysteine.

\section{CONCLUSIONS}

The single-drug/single-target paradigm of most antibiotics may not apply to INH. There are twelve INH-pyridine nucleotide metabolites (6), each one potentially targeting a different enzyme. We demonstrate here that there are at least eighteen proteins that bind INH-NAD(P) adducts with high affinity. There may be even more proteins in the M. tuberculosis proteome that we failed to isolate and identify because they may not be sufficiently abundant, they may be expressed only in vivo, or they may be sterically-prevented from binding because of the covalent attachment of INH-NAD $(\mathrm{P})$ via the exocyclic adenine amine to the solid support. We believe that this study will encourage gene knock-out studies of the genes we have identified here to determine if they are essential for in vitro and in vivo growth of $M$. tuberculosis. We also believe that this study may assist in guiding the identification of mutations, within the 
genes we identified, in M. tuberculosis INH-resistant clinical isolates for which the genotypes are presently unknown (15).

The treatment of tuberculosis involves the co-administration of four drugs, most of which are synthetic compounds specific to the treatment of this human disease. Many of these, like isoniazid, are pro-drugs (15), including ethionamide (50,51), pyrazinamide (52) and the nitroimidazole, PA-824 (53), which is being tested for its activity against the persisting population of organisms (54). In many cases, scant evidence exists for the active form of the drug, or its intracellular mycobacterial target. The emergence of multidrug resistant (isoniazid and rifampicin resistant) clinical isolates is threatening the effectiveness of these few compounds, forcing clinicians to resort to less effective, more toxic and more expensive treatment options. The proteins and enzymes that we have identified in this study appear to provide promising new candidates for biochemical- and structure-based inhibitor design that could lead to new therapeutic approaches for the control and eradication of tuberculosis.

\section{Supplementary Material}

Refer to Web version on PubMed Central for supplementary material.

\section{ACKNOWLEDGMENTS}

RawFileExtractor is an in-house script written by Dr. Christopher Paulse. Mycobacterium tuberculosis H37Rv whole cell lysate was received as part of the National Institutes of Health and National Institutes of Allergy and Infectious Disease Contract No. HHSN266200400091C, entitled “Tuberculosis Vaccine Testing and Research Materials”, which was awarded to the Colorado State University. Michael Yu provided guidance with in-gel trypsin digests.

This work was supported by a US National Institutes of Health Grant to J.S.B. (AI33396).

\section{ABBREVIATIONS}

ACP, acyl carrier protein

DHFR, dihydrofolate reductase

InhA, enoyl-ACP reductase

EDTA, ethylenediaminetetraacetic acid

INH, isonicotinic acid hydrazide (isoniazid)

INH-NAD $(\mathrm{P})$, isonicotinoylated nicotinamide adenine dinucleotides

$\mathrm{NAD}(\mathrm{P})^{+}$, oxidized nicotinamide adenine dinucleotide (phosphate)

$\mathrm{NAD}(\mathrm{P}) \mathrm{H}$, reduced nicotinamide adenine dinucleotide (phosphate)

Pipes, piperazine-1,4-bis(2-ethanesulfonic acid)

SDS-PAGE, sodium dodecylsulfate polyacrylamide gel electrophoresis

Tris, tris(hydromethyl)aminomethane

\section{REFERENCES}

1. Bernstein J, Lott WA, Steinberg BA, Yale HL. Chemotherapy experimental tuberculosis. V. Isonicotinic acid hydrazide (nydrazid) and related compounds. Am. Rev. Tuberc 1952;65:357-364. [PubMed: 14903503]

2. Youatt J. A review of the action of isoniazid. Am. Rev. Respir. Dis 1969;99:729-749. [PubMed: 4306211]

3. Bloom BR, Murray CJ. Tuberculosis: commentary on a reemergent killer. Science 1992;257:10551064. [PubMed: 1509256]

4. Zhang Y, Heym B, Allen B, Young D, Cole S. The catalaseperoxidase gene and isoniazid resistance of Mycobacterium tuberculosis. Nature 1992;358:591-593. [PubMed: 1501713] 
5. Banerjee A, Dubnau E, Quemard A, Balasubramanian V, Um KS, Wilson T, Collins D, de Lisle G, Jacobs WR Jr. InhA, a gene encoding a target for isoniazid and ethionamide in Mycobacterium tuberculosis. Science 1994;263:227-230. [PubMed: 8284673]

6. Nguyen M, Claparols C, Bernadou J, Meunier B. A fast and efficient metal-mediated oxidation of isoniazid and identification of isoniazid-NAD(H) adducts. Chembiochem 2001;2:877-883. [PubMed: 11948876]

7. Rawat R, Whitty A, Tonge PJ. The isoniazid-NAD adduct is a slow, tight-binding inhibitor of InhA, the Mycobacterium tuberculosis enoyl reductase: adduct affinity and drug resistance. Proc. Natl. Acad. Sci. U. S. A 2003;100:13881-13886. [PubMed: 14623976]

8. Rozwarski DA, Grant GA, Barton DH, Jacobs WR Jr. Sacchettini JC. Modification of the NADH of the isoniazid target (InhA) from Mycobacterium tuberculosis. Science 1998;279:98-102. [PubMed: 9417034]

9. White, SW.; Zheng, J.; Zhang, YM.; Rock, CO. The structural biology of type II fatty acid biosynthesis; Annu. Rev. Biochem. 2004. p. 791-831.

10. Vilcheze C, Morbidoni HR, Weisbrod TR, Iwamoto H, Kuo M, Sacchettini JC, Jacobs WR Jr. Inactivation of the InhA-encoded fatty acid synthase II (FAS II) enoyl-acyl carrier protein reductase induces accumulation of the FAS I end products and cell lysis of Mycobacterium smegmatis. J. Bacteriol 2000;182:4059-4067. [PubMed: 10869086]

11. Barry CE 3rd, Lee RE, Mdluli K, Sampson AE, Schroeder BG, Slayden RA, Yuan Y. Mycolic acids: structure, biosynthesis and physiological functions. Prog. Lipid Res 1998;37:143-179. [PubMed: 9829124]

12. Takayama K, Wang C, Besra GS. Pathway to synthesis and processing of mycolic acids in Mycobacterium tuberculosis. Clin. Microbiol. Rev 2005;18:81-101. [PubMed: 15653820]

13. Argyrou, A.; Vetting, MW.; Aladegbami, B.; Blanchard, JS. Mycobacterium tuberculosis dihydrofolate reductase is a target for isoniazid. Nat. Struct. Mol. Biol. 2006.

14. Miller GP, Benkovic SJ. Stretching exercises--flexibility in dihydrofolate reductase catalysis. Chem. Biol 1998;5:R105-113. [PubMed: 9578637]

15. Zhang, Y.; Vilcheze, C.; Jacobs, WR, Jr.. Tuberculosis and the Tubercle Bacillus. Cole, ST.; Eisenach, KD.; McMurray, DN.; Jacobs, WR., Jr., editors. ASM Press; Washington, D. C: 2005. p. 115-140.

16. Cole ST, Brosch R, Parkhill J, Garnier T, Churcher C, Harris D, Gordon SV, Eiglmeier K, Gas S, Barry CE 3rd, Tekaia F, Badcock K, Basham D, Brown D, Chillingworth T, Connor R, Davies R, Devlin K, Feltwell T, Gentles S, Hamlin N, Holroyd S, Hornsby T, Jagels K, Krogh A, McLean J, Moule S, Murphy L, Oliver K, Osborne J, Quail MA, Rajandream MA, Rogers J, Rutter S, Seeger K, Skelton J, Squares R, Squares S, Sulston JE, Taylor K, Whitehead S, Barrell BG. Deciphering the biology of Mycobacterium tuberculosis from the complete genome sequence. Nature 1998;393:537544. [PubMed: 9634230]

17. Miesel L, Weisbrod TR, Marcinkeviciene JA, Bittman R, Jacobs WR Jr. NADH dehydrogenase defects confer isoniazid resistance and conditional lethality in Mycobacterium smegmatis. J. Bacteriol 1998;180:2459-2467. [PubMed: 9573199]

18. Vilcheze C, Weisbrod TR, Chen B, Kremer L, Hazbon MH, Wang F, Alland D, Sacchettini JC, Jacobs WR Jr. Altered NADH/NAD ${ }^{+}$ratio mediates coresistance to isoniazid and ethionamide in mycobacteria. Antimicrob. Agents Chemother 2005;49:708-720. [PubMed: 15673755]

19. Pasca MR, Guglierame P, De Rossi E, Zara F, Riccardi G. mmpL7 gene of Mycobacterium tuberculosis is responsible for isoniazid efflux in Mycobacterium smegmatis. Antimicrob. Agents Chemother 2005;49:4775-4777. [PubMed: 16251328]

20. Alland D, Kramnik I, Weisbrod TR, Otsubo L, Cerny R, Miller LP, Jacobs WR Jr. Bloom BR. Identification of differentially expressed mRNA in prokaryotic organisms by customized amplification libraries (DECAL): the effect of isoniazid on gene expression in Mycobacterium tuberculosis. Proc. Natl. Acad. Sci. U. S. A 1998;95:13227-13232. [PubMed: 9789070]

21. Wilson M, DeRisi J, Kristensen HH, Imboden P, Rane S, Brown PO, Schoolnik GK. Exploring druginduced alterations in gene expression in Mycobacterium tuberculosis by microarray hybridization. Proc. Natl. Acad. Sci. U. S. A 1999;96:12833-12838. [PubMed: 10536008]

22. Betts JC, McLaren A, Lennon MG, Kelly FM, Lukey PT, Blakemore SJ, Duncan K. Signature gene expression profiles discriminate between isoniazid-, thiolactomycin-, and triclosan-treated 
Mycobacterium tuberculosis. Antimicrob. Agents Chemother 2003;47:2903-2913. [PubMed: 12936993]

23. Boshoff HI, Myers TG, Copp BR, McNeil MR, Wilson MA, Barry CE 3rd. The transcriptional responses of Mycobacterium tuberculosis to inhibitors of metabolism: novel insights into drug mechanisms of action. J. Biol. Chem 2004;279:40174-40184. [PubMed: 15247240]

24. Waddell SJ, Stabler RA, Laing K, Kremer L, Reynolds RC, Besra GS. The use of microarray analysis to determine the gene expression profiles of Mycobacterium tuberculosis in response to anti-bacterial compounds. Tuberculosis (Edinb) 2004;84:263-274. [PubMed: 15207496]

25. Hughes MA, Silva JC, Geromanos SJ, Townsend CA. Quantitative proteomic analysis of druginduced changes in mycobacteria. J. Proteome Res 2006;5:54-63. [PubMed: 16396495]

26. Smith PK, Krohn RI, Hermanson GT, Mallia AK, Gartner FH, Provenzano MD, Fujimoto EK, Goeke NM, Olson BJ, Klenk DC. Measurement of protein using bicinchoninic acid. Anal. Biochem 1985;150:76-85. [PubMed: 3843705]

27. Ducasse-Cabanot S, Cohen-Gonsaud M, Marrakchi H, Nguyen M, Zerbib D, Bernadou J, Daffe M, Labesse G, Quemard A. In vitro inhibition of the Mycobacterium tuberculosis beta-ketoacyl-acyl carrier protein reductase MabA by isoniazid. Antimicrob. Agents Chemother 2004;48:242-249. [PubMed: 14693546]

28. Lei B, Wei CJ, Tu SC. Action mechanism of antitubercular isoniazid. Activation by Mycobacterium tuberculosis KatG, isolation, and characterization of InhA inhibitor. J. Biol. Chem 2000;275:25202526. [PubMed: 10644708]

29. Oda Y, Owa T, Sato T, Boucher B, Daniels S, Yamanaka H, Shinohara Y, Yokoi A, Kuromitsu J, Nagasu T. Quantitative chemical proteomics for identifying candidate drug targets. Anal. Chem 2003;75:2159-2165. [PubMed: 12720356]

30. Mdluli K, Slayden RA, Zhu Y, Ramaswamy S, Pan X, Mead D, Crane DD, Musser JM, Barry CE 3rd. Inhibition of a Mycobacterium tuberculosis beta-ketoacyl ACP synthase by isoniazid. Science 1998;280:1607-1610. [PubMed: 9616124]

31. Palmer JL, Abeles RH. The mechanism of action of $S$-adenosylhomocysteinase. J. Biol. Chem 1979;254:1217-1226. [PubMed: 762125]

32. Kloor D, Osswald H. S-Adenosylhomocysteine hydrolase as a target for intracellular adenosine action. Trends Pharmacol. Sci 2004;25:294-297. [PubMed: 15165742]

33. Stepkowski T, Brzezinski K, Legocki AB, Jaskolski M, Bena G. Bayesian phylogenetic analysis reveals two-domain topology of $S$-adenosylhomocysteine hydrolase protein sequences. Mol. Phylogenet. Evol 2005;34:15-28. [PubMed: 15579379]

34. Chen P, Bishai WR. Novel selection for isoniazid (INH) resistance genes supports a role for NAD ${ }^{+}$ binding proteins in mycobacterial INH resistance. Infect. Immun 1998;66:5099-5106. [PubMed: 9784509]

35. Wierenga RK, Terpstra P, Hol WG. Prediction of the occurrence of the ADP-binding beta alpha betafold in proteins, using an amino acid sequence fingerprint. J. Mol. Biol 1986;187:101-107. [PubMed: 3959077]

36. Kvint K, Nachin L, Diez A, Nystrom T. The bacterial universal stress protein: function and regulation. Curr. Opin. Microbiol 2003;6:140-145. [PubMed: 12732303]

37. Boon C, Li R, Qi R, Dick T. Proteins of Mycobacterium bovis BCG induced in the Wayne dormancy model. J. Bacteriol 2001;183:2672-2676. [PubMed: 11274129]

38. Rosenkrands I, Slayden RA, Crawford J, Aagaard C, Barry CE 3rd, Andersen P. Hypoxic response of Mycobacterium tuberculosis studied by metabolic labeling and proteome analysis of cellular and extracellular proteins. J. Bacteriol 2002;184:3485-3491. [PubMed: 12057942]

39. Florczyk MA, McCue LA, Stack RF, Hauer CR, McDonough KA. Identification and characterization of mycobacterial proteins differentially expressed under standing and shaking culture conditions, including Rv2623 from a novel class of putative ATP-binding proteins. Infect. Immun 2001;69:57775785. [PubMed: 11500455]

40. Monahan IM, Betts J, Banerjee DK, Butcher PD. Differential expression of mycobacterial proteins following phagocytosis by macrophages. Microbiology 2001;147:459-471. [PubMed: 11158363] 
41. Shi L, Jung YJ, Tyagi S, Gennaro ML, North RJ. Expression of Th1-mediated immunity in mouse lungs induces a Mycobacterium tuberculosis transcription pattern characteristic of nonreplicating persistence. Proc. Natl. Acad. Sci. U. S. A 2003;100:241-246. [PubMed: 12506197]

42. Hingley-Wilson SM, Sambandamurthy VK, Jacobs WR Jr. Survival perspectives from the world's most successful pathogen, Mycobacterium tuberculosis. Nat. Immunol 2003;4:949-955. [PubMed: 14515128]

43. Basso LA, Zheng R, Musser JM, Jacobs WR Jr. Blanchard JS. Mechanisms of isoniazid resistance in Mycobacterium tuberculosis: enzymatic characterization of enoyl reductase mutants identified in isoniazid-resistant clinical isolates. J. Infect. Dis 1998;178:769-775. [PubMed: 9728546]

44. Musser JM. Antimicrobial agent resistance in mycobacteria: molecular genetic insights. Clin. Microbiol. Rev 1995;8:496-514. [PubMed: 8665467]

45. Winder FG, Collins PB. Inhibition by isoniazid of synthesis of mycolic acids in Mycobacterium tuberculosis. J. Gen. Microbiol 1970;63:41-48. [PubMed: 5500025]

46. Takayama K, Wang L, David HL. Effect of isoniazid on the in vivo mycolic acid synthesis, cell growth, and viability of Mycobacterium tuberculosis. Antimicrob. Agents Chemother 1972;2:2935. [PubMed: 4208567]

47. Quemard A, Lacave C, Laneelle G. Isoniazid inhibition of mycolic acid synthesis by cell extracts of sensitive and resistant strains of Mycobacterium aurum. Antimicrob. Agents Chemother 1991;35:1035-1039. [PubMed: 1656850]

48. Gangadharam PR, Harold FM, Schaefer WB. Selective inhibition of nucleic acid synthesis in Mycobacterium tuberculosis by isoniazid. Nature 1963;198:712-714. [PubMed: 13946383]

49. Sassetti CM, Boyd DH, Rubin EJ. Genes required for mycobacterial growth defined by high density mutagenesis. Mol. Microbiol 2003;48:77-84. [PubMed: 12657046]

50. DeBarber AE, Mdluli K, Bosman M, Bekker LG, Barry CE 3rd. Ethionamide activation and sensitivity in multidrug-resistant Mycobacterium tuberculosis. Proc. Natl. Acad. Sci. U. S. A 2000;97:96779682. [PubMed: 10944230]

51. Baulard AR, Betts JC, Engohang-Ndong J, Quan S, McAdam RA, Brennan PJ, Locht C, Besra GS. Activation of the pro-drug ethionamide is regulated in mycobacteria. J. Biol. Chem 2000;275:2832628331. [PubMed: 10869356]

52. Scorpio A, Zhang Y. Mutations in $p n c A$, a gene encoding pyrazinamidase/nicotinamidase, cause resistance to the antituberculous drug pyrazinamide in tubercle bacillus. Nat. Med 1996;2:662-667. [PubMed: 8640557]

53. Stover CK, Warrener P, VanDevanter DR, Sherman DR, Arain TM, Langhorne MH, Anderson SW, Towell JA, Yuan Y, McMurray DN, Kreiswirth BN, Barry CE, Baker WR. A small-molecule nitroimidazopyran drug candidate for the treatment of tuberculosis. Nature 2000;405:962-966. [PubMed: 10879539]

54. Barry CE 3rd, Boshoff HI, Dowd CS. Prospects for clinical introduction of nitroimidazole antibiotics for the treatment of tuberculosis. Curr. Pharm. Des 2004;10:3239-3262. [PubMed: 15544513]

55. Suling WJ, Reynolds RC, Barrow EW, Wilson LN, Piper JR, Barrow WW. Susceptibilities of Mycobacterium tuberculosis and Mycobacterium avium complex to lipophilic deazapteridine derivatives, inhibitors of dihydrofolate reductase. J. Antimicrob. Chemother 1998;42:811-815. [PubMed: 10052907] 
<smiles>NC(=O)C1=CN([R17](=O)[O-])C=C[C@H]1C(=O)c1ccncc1</smiles>

1<smiles></smiles>

2

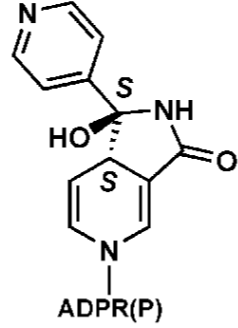

3<smiles></smiles>

4<smiles></smiles>

5

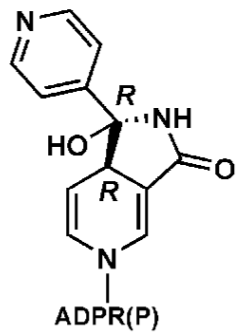

6

FIGURE 1.

Chemical structures of the INH-NAD and INH-NADP adducts. The adenosinediphosphoribose (for INH-NAD) and 2'-phospho-adenosine-diphospho-ribose (for INH-NADP) moiety of these molecules is abbreviated as $\operatorname{ADPR}(\mathrm{P})$. Each of the $R$ and $S$ acyclic forms is in equilibrium with the corresponding pair of diastereomeric, cyclic, hemiaminal forms. Cyclization occurs by intramolecular attack of the amide nitrogen of the nicotinamide ring on the carbonyl group of the isonicotinoyl moiety (6). 


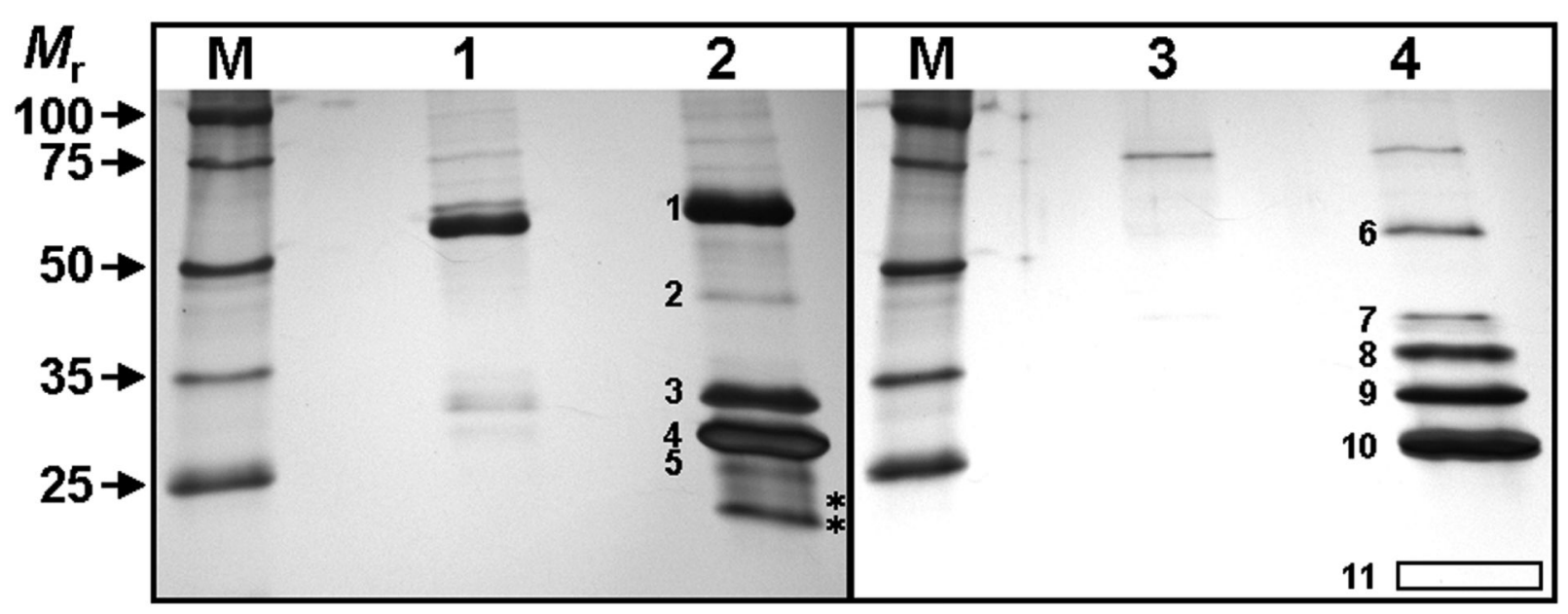

FIGURE 2.

SDS-PAGE of the INH-NAD $(\mathrm{P})$ protein eluates from the $\mathrm{NAD}^{+}$-sepharose (lane 1), INHNAD-sepharose (lane 2), NADP ${ }^{+}$-sepharose (lane 3), and INH-NADP-sepharose (lane 4) columns. The gels were silver-stained. The two lanes marked $M$ represent molecular weight markers. The identities of the protein bands marked with numbers are shown in Table 1 . The two bands marked with an asterisk (lane 2) correspond to degradation products of band 4 (InhA). 


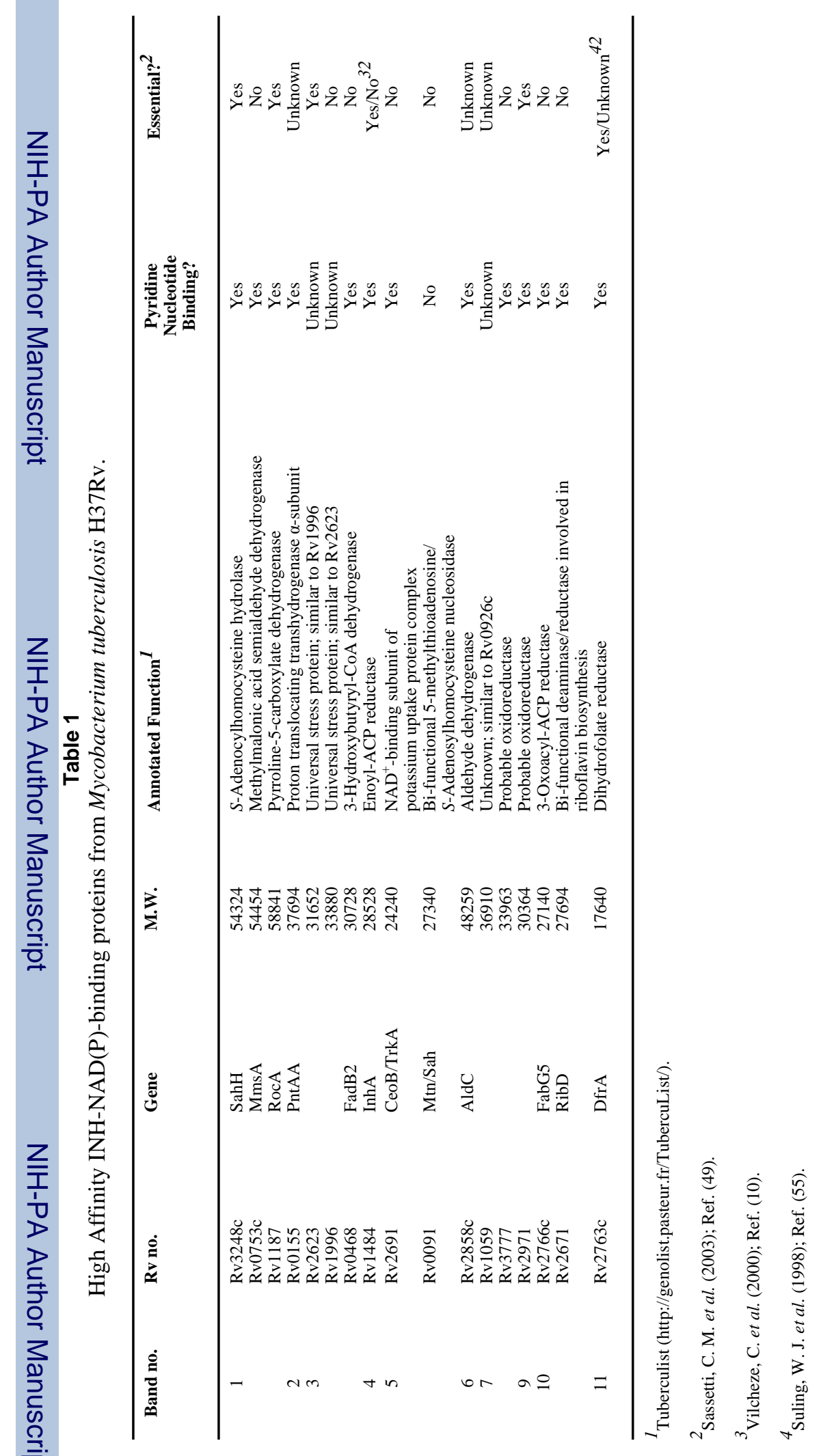

